Review Article

\title{
IMPACT OF ACTIVE PHARMACEUTICAL INGREDIENT (API) SCARCITY IN PHARMACEUTICAL SECTORS AMIDST COVID-19 PANDEMIC
}

\author{
ARPAN SAHA ${ }^{*}$, SANTANU MALLIK ${ }^{2}$ \\ ${ }^{1 *}$ Department of Pharmaceutical Chemistry, Bharat Pharmaceutical Technology, Amtali, Tripura, India 799130, 2Department of \\ Pharmaceutics, Bharat Pharmaceutical Technology, Amtali, Tripura, India 799130 \\ Email: sahaarpan150@gmail.com
}

Received: 30 Apr 2019, Revised and Accepted: 07 Oct 2020

\begin{abstract}
The novel coronavirus disease 2019 (COVID-19) was characterized as a global pandemic by the World Health Organization (WHO) on March 11, 2020. The present pandemic has caused an intolerable impact on the health structure as well as the pharmaceutical sector, which in ultimatum has created enormous issues in the everyday lives of the patient community. On the other hand, the situation may appear in short and long-term timehorizon and need identification along with appropriate planning to reduce their socio-economic burden. The Indian pharmaceutical industry is the world's third-largest drug producer by volume. India supplies affordable and low-cost generic drugs to millions of people around the globe and operates more than 250 United States Food and Drug Administration (USFDA) and United Kingdom Medicine and Healthcare products Regulatory Agency (UKMHRA) approved plants. Given the Indian pharmaceutical industry, the source of Active Pharmaceutical Ingredients (APIs) for multiple diseases is much crucial part of the Pharma industry's strategic plan to combat the COVID-19 pandemic. China is the top global producer and exporter of APIs by volume and Indian pharmaceutical industries are also rely heavily on APIs from China for the production of their medicine formulations by importing around 70 percent of the total requirement. However, the present pandemic situation has exposed the world's overreliance on China in terms of API import and bound world leaders to fig. out sustainable alternatives.
\end{abstract}

Keywords: Active pharmaceutical ingredients, Coronavirus, Pharmaceutical industry, COVID-19, Health and Government policy

(C) 2020 The Authors. Published by Innovare Academic Sciences Pvt Ltd. This is an open access article under the CC BY license (http://creativecommons.org/licenses/by/4.0/) DOI: http://dx.doi.org/10.22159/ijpps.2020v12i12.39396. Journal homepage: https://innovareacademics.in/journals/index.php/ijpps.

Speedy peer review was done as the subject of the manuscript was related with pandemic.

\section{INTRODUCTION}

The review of literature related to the present systematic review study was carried out in the period from April 2020 to October 2020. The search terms used were 'active pharmaceutical ingredients', 'coronavirus', 'pharmaceutical industry', 'COVID-19', 'Indian API scarcity', pharmaceutical raw material', 'growth development index', 'future proposal of API industry'. The present search and study were carried out by referring to various journals containing peer review and research papers and the latest scientific magazines and electronic media publications. The electronic databases used were Science Direct, Pub Med, Web of Science, Scopus which provides free access to Medline, Google and Google scholar. Only published contents in English languages were used for the more comprehensive study to make the latest review article on API Scarcity during the coronavirus pandemic. Reference lists of articles were also cross-checked for authentication.

Active Pharmaceutical Ingredients (APIs) means the effective ingredient which is contained in the medicine. For instance, considering the case of the commercially available pharmaceutical product from any company which is used to reduce normal body ache and fever, the API Paracetamol is the active pharmaceutical component contained in the product that gives relief from body ache and fever for which the mentioned medicine is prescribed or taken. Whereas, fixed-dose combination drug use several APIs, while single-dose drugs were made of just one APIs [1, 2].

A very small amount of the active ingredient can be able to produce therapeutic effects. Thus, only a small part of the active ingredient is generally contained in the medicines. Nevertheless, APIs and raw materials are frequently confusing due to the similar usage of both the terms. Raw material relates to chemical compounds that are used as a base to make an API. Whereas, the API is not only made by a single reaction from the raw materials but rather it becomes an API via several chemical compounds. The chemical compound which is in the process of coming to be an API from raw material is called an 'intermediate'. There are also some APIs that involve more than ten kinds of intermediates in a process related to the conversion of raw materials into an API $[1,3]$.

Apart from APIs, a medicine contains chemically inactive components termed as 'excipients' which do the job of delivering the effect of APIs to the human body system. An API manufacturer first develops the chemical compound in a laboratory after which the production department manufactures a bulk amount of APIs using large size reactors. Finally, these are checked for purity, before selling it to the drug makers. The quality of an API is one of the most important factors in view of appropriate effectiveness of the medicine. Furthermore, the active pharmaceutical ingredients (APIs) market in our country is forecasted to attain revenue of $\$ 6$ billion by the end of 2020 [2-4].

\section{Impact of covid-19 pandemic}

The world is now in an alarming situation amid the pandemic coronavirus disease and due to which it has been shown that there is a huge scarcity regarding APIs which are very much integral parts to make medicine or medical products $[3,4]$. The Indian pharmaceutical industry is highly dependent on China. About $70 \%$ of raw materials for APIs in India are imported from China [5]. But the periodic lockdowns prevailing in both the countries due to the COVID-19 pandemic situation has a massive negative impact on the international supply and export-import of goods.-The bilateral relations between both countries are aggressively turning day by day towards an enmity. Thus, all these factors are constructively contributing to the APIs scarcity in India in a very significant way $[1,4,6]$.

Due to this pandemic outbreak, supplies of raw materials from China to produce drugs for treating chronic diseases like HIV, cancer epilepsy, malaria, and even many commonly used antibiotics and vitamin pills, were affected the most. Industry insiders panic that the coronavirus created supply constraints that may lead to shortages of cardiovascular and antibiotic categories of drugs $[2,5,7]$. The domestic pharmaceutical industry is highly dependent on imports with more than 60 percent of its API requirement being shipped 
inand in some specific cases active pharmaceutical ingredients like cephalosporins, azithromycin, and penicillin. Because the dependence is as high as 80 to 90 percent. Moreover, supply-side constraints and risks of contamination are also expected to add fuel to the shortages of certain kinds of medicines $[6,8]$.

The COVID-19 pandemic situation resulted in immense cost increases in drugs. For instance, Penicillin's raw material became 40 percent costlier in just a month. According to data from the Pharmaceutical Export Promotion Council (PHARMEXCIL), which functions under the Ministry of Commerce and Industry, the cost of API Penicillin has increased to Rs. 7639.00 (\$8.69) per unit at the time of writing this article, against Rs. $\$ 454.00$ (\$6.16) per unit in January 2020. $[9,10]$. Data collected by API manufacturers further suggests that there is a rise of 13 to 18 percent in the prices of APIs for other antibiotics such as Azithromycin, Doxycycline, Amikacin, Ornidazole, and Dexamethasone Sodium, etc. and India imports most of them from China. Meanwhile, the price of Paracetamol, an API widely used as painkiller and during fever has increased by 26 percent in January [11-13]

The Indian regulatory agency predicts that more than 50 APIs of crucial antibiotics, vitamins, and hormones or steroids could go out of stock in case of a prolonged lockdown in China. 'Montelukast sodium' (an anti-asthmatic drug) is now trading between Rs. ₹52,000 Rs. ₹58,000 (\$705.93-\$787.38) per $\mathrm{kg}$, compared to Rs. $\$ 33,000$ to Rs. 38,000 (\$447.99-\$515.87) per kg a few months ago. Similarly, the prices of vitamins and penicillin have increased by 40 50 percent and the majorities of the vitamins are trading at double or triple the original price $[14,15,16]$. The companies may end up exhausting most of their stock of active ingredients for high-demand of drugs like Paracetamol and Ibuprofen. Moreover, the impact is set to be grave, as most of those materials are largely manufactured in the Hubei province whose capital, Wuhan has been the initial epicenter of the COVID-19 outbreak. The neighboring areas of Zhejiang and Jiangsu are the other two major Chinese centers of medicinal raw material production. Hubei province supply 30 to 40 categories of basic chemicals, APIs, intermediates to India and about Rs. 17,400 crore APIs have been imported from all over China. $[9,17]$.

India's drug pricing regulator has allowed pharmaceutical companies to raise the ceiling price of essential medicine like heparin by 50 percent until December 31, 2020. Heparin is an anticoagulant or antiplatelet drug that has long been used in patients vulnerable to blood clots in their legs, lungs, heart, or other body parts. It is used to reduce the risk of heart attacks, strokes, and lung or pulmonary embolism. Several patients with critical illnesses, including those requiring dialysis or kidney, are given the drug $[18,19]$.

During the Covid-19 pandemic, the Ministry of Health and Family Welfare (MoHFW) included the drug in its clinical management guidelines for the treatment of Covid-19 patients in the Intensive Care Units. Still, there have been instances of deficiency of this drug during this pandemic situation. National Pharmaceutical Pricing Authority (NPPA) used extraordinary emergency powers provided to it under paragraph 19 of the Drugs Prices Control Order (DPCO), 2013. This is for the first time that NPPA increased the prices of medicines under the price control by 50 percent in comparison to December 2019. The prices of 21 numbers of drugs were increased, which are integral to various public health programs and often used as the first line choice of treatment $[15,20]$.

Table 1: World-wide impact of COVID-19 on the pharmaceutical sector

\begin{tabular}{|c|c|c|c|c|c|c|}
\hline \multicolumn{3}{|l|}{ Impact } & \multirow{2}{*}{$\begin{array}{l}\text { Middle East } \\
\uparrow \text { in } 10 \% \text { of OTC category } \\
\text { (cold and cough) drugs }\end{array}$} & \multirow{2}{*}{$\begin{array}{l}\text { EU Countries } \\
\uparrow \text { in } 10 \% \text { of OTC } \\
\text { category (vitamins, } \\
\text { minerals, etc.) }\end{array}$} & \multirow{2}{*}{$\begin{array}{l}\text { United States } \\
\text { Investigational treatments } \\
\text { have seen a } 2 \text {-fold } \uparrow\end{array}$} & \multirow{3}{*}{$\begin{array}{l}\text { Reference } \\
21\end{array}$} \\
\hline $\begin{array}{l}\text { Short } \\
\text { term } \\
\text { impact }\end{array}$ & $\begin{array}{l}\text { Induced Demands } \\
\text { and Medication } \\
\text { shortage }\end{array}$ & Covid-19 related & & & & \\
\hline & & & $\uparrow 403 \%$ in Personal hygiene & $\begin{array}{l}\text { Tin } 62 \% \text { of personal } \\
\text { hygiene }\end{array}$ & $\begin{array}{l}\text { Medicines used in hospitals } \\
\text { for the treatment of Covid-19 } \\
\text { have } \uparrow \text { between } 100 \% \text { and } \\
700 \% \text { since January } 2020\end{array}$ & \\
\hline & & & $\uparrow i n 67 \%$ of ICU medications & & & \\
\hline & & $\begin{array}{l}\text { General like Panic } \\
\text { buying }\end{array}$ & $\begin{array}{l}\text { Tin } 23 \% \text { of Lipid-lowering } \\
\text { drugs }\end{array}$ & $\begin{array}{l}\text { } \text { in } 7 \% \text { of highest } \\
\text { volume growth in } \\
\text { ATCN class of Rx- } \\
\text { category in Spain }\end{array}$ & $\begin{array}{l}\text { Excess of prescriptions for } \\
\text { hypertension-7, Mental } \\
\text { health-6, Respiratory-5, } \\
\text { Diabetes-4 (in million) }\end{array}$ & \\
\hline & & & $\begin{array}{l}\text { Tin } 40 \% \text { of Anti-diabetes } \\
\text { drugs }\end{array}$ & - & - & \\
\hline & & & $\begin{array}{l}\text { in } 29.1 \% \text { of } \\
\text { antihypertensive drugs }\end{array}$ & - & 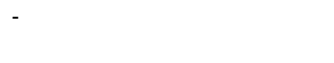 & \\
\hline & & Shortage of supply & $\begin{array}{l}\text { Medicines for chronic } \\
\text { diseases were at high risk of } \\
\text { shortage or supply chain. }\end{array}$ & - & $\begin{array}{l}\text { The supply shortage of both } \\
\text { active APIs and finished } \\
\text { products }\end{array}$ & \\
\hline & & - & - & - & $\begin{array}{l}\text { The supply shortage of Covid- } \\
19 \text { related complications } \\
\text { treatment }\end{array}$ & \\
\hline & Research and develo & ent Shifts & $\begin{array}{l}156 \text { clinical trials are } \\
\text { running for Covid-19 }\end{array}$ & $\begin{array}{l}140 \text { clinical trials are } \\
\text { running for covid-19 }\end{array}$ & - & \\
\hline & $\begin{array}{l}\text { Shifts towards } \\
\text { telemedicine }\end{array}$ & $\begin{array}{l}\text { WhatsApp call is the } \\
\text { most preferred digital } \\
\text { channel for both } \\
\text { communications }\end{array}$ & $\begin{array}{l}\uparrow \text { in } 320 \% \text { (v. PY) in remote } \\
\text { interactions in Spain. The } \uparrow \text { in } \\
\text { Italy (v. PY) was } 471 \%\end{array}$ & $\begin{array}{l}70-80 \% \downarrow \text { in the } \\
\text { number of patient } \\
\text { visits to doctors }\end{array}$ & - & \\
\hline & - & $\begin{array}{l}\text { Digital channel has } \\
\text { wide adoption with } \\
\text { over } 75 \%\end{array}$ & $\begin{array}{l}\downarrow \text { in } 51 \% \text { in specialist } \\
\text { consultations and } \downarrow \text { in } 25 \% \text { in } \\
\text { GPs visits }\end{array}$ & $\begin{array}{l}\text { Tele-medicine } \\
\text { growth accounts for } \\
23 \% \text { of interactions }\end{array}$ & - & \\
\hline \multirow[t]{3}{*}{$\begin{array}{l}\text { Wide } \\
\text { impact }\end{array}$} & $\begin{array}{l}\text { Approval delays } \\
\text { (Non-Covid-19 } \\
\text { products) }\end{array}$ & $\begin{array}{l}\text { Clinical trial 8\% delay } \\
\text { existing enrolment }\end{array}$ & $\begin{array}{l}\text { Pharma companies report a } \\
\text { delay in new trial starts }\end{array}$ & - & - & \\
\hline & - & $\begin{array}{l}16 \% \text { delay new trials } \\
\text { only } 32 \% \text { delay new } \\
\text { trials and existing } \\
\text { patient enrolment }\end{array}$ & $\begin{array}{l}\text { Product launches delayed, } \\
\text { disrupted, or impacted }\end{array}$ & - & - & \\
\hline & $\begin{array}{l}\text { Shifts towards self- } \\
\text { sufficiency in the } \\
\text { pharma industry }\end{array}$ & - & $\begin{array}{l}\text { Direct investment and free } \\
\text { movement of capital }\end{array}$ & - & - & \\
\hline
\end{tabular}

v. PY: versus Previous Year, APIs: Active Pharmaceutical Ingredients, OTC: Over the Counter, ATCN: Anatomical Therapeutic Chemical Classification Nervous system, GPs: General Practitioners, RandD: Research and Development, ICU: Intensive Care Unit, EU: European countries, $\uparrow:$ Increase, $\downarrow$ : Decrease. 
Such important drug includes, Bacilli Calmette-Guerin (BCG) vaccine for tuberculosis disease, vitamin $\mathrm{C}$, antibiotics like metronidazole and benzylpenicillin, anti-malarial drug-like chloroquine, and leprosy medication like dapsone. The heparin sodium API for the manufacturing of injections in India was majorly comes from China. It means that a snag in the supply chain from China could disrupt the availability of medicines made in India and for the rest of the World. Such dependency will definitely hit the availability of medicines in other countries that imports from India as well. The shipments of drugs like paracetamol, erythromycin salts, Vitamins B1, B6, and B12, acyclovir, and progesterone were only allowed to import with a no-objection certificate (NOC) that companies claimed were difficult to procure. This was around the time that Wuhan province in China, from where these Active Pharmaceutical Ingredients were mostly imported, was under a strict COVID-19 pandemic lockdown. Table 1 represents the world wide impact of the COVID-19 pandemic on the Pharmaceutical sector [21].

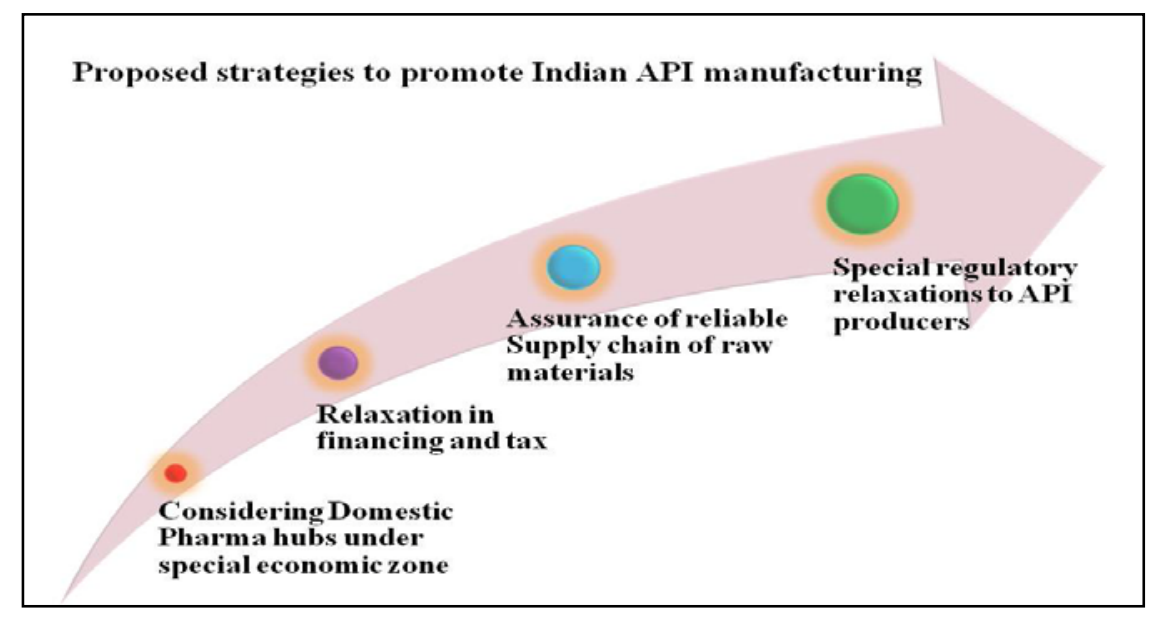

Fig. 1: Proposed future strategies to make self-resilient India in API manufacturing [22]

To combat the rapid rise in API prices during this pandemic, the Indian pharmaceutical industry needs to develop and implement a robust strategy very quickly. Policy makers should first start by setting short term goals. The existent domestic players must be improved and incentivized to eventually set them up for the global competition in the long term. Most of the focus must be on ease of doing business which will invite more startups and manufacturers to the indigenous pharmaceutical field. The long-term goal must be to become self-sufficient in the next two to three years. In that case, the Government must set up timelines for the organizations to speed up policy implementation [fig. 1]. Necessary steps must also be taken by the respective State Governments [22-24].

Some states like Telangana, Haryana, Gujarat, and Himachal Pradesh have already initiated the allocation of lands for bulk drug production. It is the right time for the industries to start building facilities $[25,26]$. Other supporting measures like tax incentives, early clearance from the respective pollution boards, and other agencies for the respective companies, must also be initiated. There must be uniformity in the policies across all the states of the country $[25,27]$. The prime key is to implement all these very quickly to have a substantial positive impact within the next few years [28]. It must also be remembered that the efforts of the government should be continued even after the COVID-19 phase to make India a globally recognized force in the API industry [29].

Our Country needs clear and proactive interventions to ensure an all-conducive supply chain. This will not only boost local manufacturing but also find ways to reduce dependence on external factors. The government launched targeted financial incentives to promote the manufacturing of raw materials, and to bring back a larger production of APIs to India [30,31]. The Union Cabinet took a decisive step to establish three API parks with common utilities, identifying and reducing the dependencies on China for, introduced the Production Linked Incentive (PLI) scheme to further reiterate India's aim to be self-reliant [32]. The government needs to efficiently use existing API units. The shortage of delivery points and the lack of accessibility to drugs continue to be bottlenecks even for the pharmaceutical companies to fully utilize the domestic market. The affordability of drugs will rise due to sustained growth in incomes and an increase in insurance coverage [33, 34]. Greater spending on healthcare and government-sponsored programs are necessary to cover the rural markets. Improving economic growth is imperative for investments in healthcare infrastructure and financing, and higher per capita disposable income [35]. As various countries are willing to invest in the Indian market for the supply of COVID-19 vaccine and medical equipment, this is the chance for India to become truly self-reliant in the pharmaceutical segment [36].

\section{CONCLUSION}

For a sustainable market and a robust growth rate, innovative business models should be developed for equilibrium in drug price controlling and local manufacturing costs regarding the scenario of prospects of the API industry which one is very much needed of the hour. As well as our Country needs bilateral collaboration, multilateral collaboration, to see the need of the society in this crisis mode regarding socio-economic point of view, tie-up with various good investors, to give emergency service to gear up from the present situation, smoothen the export-import challenges, and excise issues. Various Countries need to coordinate with each other because this pandemic is all about health issues so that the whole world can come back to its normal situation from this present pandemic situation. To create a special visa for upbringing scientists and professionals to grab the opportunity for the production of pharmaceutical drugs or equipment at this crucial moment and finally to think about regarding less profit from the industrial point of view. It is very much necessary for every country leaders to come together in one platform, tie up regarding various health organizations, do whatever is needed at this crucial hour.

\section{ACKNOWLEDGEMENT}

The authors are thankful to Prof. (Dr.) Rabindra Debnath, Hon. Chairman, Bharat Pharmaceutical Technology and Prof. (Dr.) Sinha Ashutosh Kumar, Principal, Bharat Pharmaceutical Technology, Amtali, Agartala, West Tripura district, Tripura, India for their kind motivation and associate support in completion of the research work.

\section{FUNDING}

Nil

\section{AUTHORS CONTRIBUTIONS}

All the authors have contributed equally.

\section{CONFLICT OF INTERESTS}

Declared none 


\section{REFERENCES}

1. katsura-chemical.co.jp [Internet]. Japan: What is an API; c2020. Available from: https://www.katsura-chemical.co.jp/en/drugs. [Last accessed on 07 Aug 2020]

2. Koenig SG, Bee C, Borovika A, Briddell C, Colberg J, Humphrey $\mathrm{GR}$, et al. A green chemistry continuum for a robust and sustainable active pharmaceutical ingredient supply chain. ACS Sustainable Chem Eng 2019;7:16937-51.

3. Chandna H. What are APIs and how they threaten India's status of a 'pharmacy to the World', The Print [Internet]; 2020. The print essential: [about 2 p.]. Available from: https://theprint.in/theprint-essential/what-are-apis-and-howthey-threaten-indias-status-of-a-pharmacy-to-theworld/370941. [Last accessed on 10 Aug 2020]

4. Oxford Analytica, Indian pharma will struggle to meet COVID19 demand. Emerald Expert Briefings, (oxan-db); 2020.

5. Hangargekar CB, Quazi RS, Joshi AA. A review on COVID-19-a global battle between life and death. Int J Curr Pharm Res 2020;12:19-24.

6. Chatterjee P. Indian pharma threatened by COVID-19 shutdowns in China. Lancet 2020;395:675.

7. Vaid R. Scarcity of China salt might cause antibiotics shortage in India, Outlook; 2020. Available from: https://www.outlookindia.com/newsscroll/scarcity-of-chinasalt-might-cause-antibiotics-shortage-in-india-iansspecial/1745072. [Last accessed on 11 Aug 2020]

8. Ramsey L, Premack R. The US could face shortages of crucial medicines like antibiotics and a heart drug because of the coronavirus, Business Insider India; 2020. Available from: https://www.businessinsider.in/science/news/the-us-couldface-shortages-of-crucial-medicines-like-antibiotics-and-aheart-drug-because-of-the-coronavirus-heres-what-you-needto-know-/articleshow/74466937.cms [Last accessed on 12 Aug 2020]

9. Athavale S. Indian pharma sector faces supply shortage the spike in costs due to the coronavirus in China, The Logical Indian; 2020. Available from: https://thelogicalindian.com/ news/pharma-price-india-china-coronavirus-19774. [Last accessed on 12 Aug 2020].

10. Yewale DA. Make in India Initiative: success or failure. Stud Ind Place Names 2020;40:148-60.

11. Bishnoi V. Make in India initiative: a key for sustainable growth. South Asian J Marketing Management Res 2019;9:21-7.

12. Parameshwar K, Pamu S, Sandeep K, Suresh CA. Review novel coronavirus. Asian J Pharm Clin Res 2020;13:12-7.

13. Rawat V. Coronavirus situation in China may hike API prices impact profits of Indian Pharma, from the economic times; 2020. Available from: https://cfo.economictimes. indiatimes.com/news/coronavirus-situation-in-china-mayhike-api-prices-impact-profits-of-indian-pharmas/73734703. [Last accessed on 12 Aug 2020]

14. Sharma U. Finding the silver lining about coronavirus pandemic, Express Pharma; 2020. Available from: https://www.expresspharma.in/cover-story/finding-thesilver-lining-about-coronavirus-pandemic/. [Last accessed on 12 Aug 2020]

15. Al-Tameemi KA, Kabakli R. Novel coronavirus (2019-nCoV): disease briefings. Asian J Pharm Clin Res 2020;13:22-7.

16. Zou P, Huo D, Li M. The impact of the COVID-19 pandemic on firms: a survey in guangdong province, China. Glob Health Res Policy 2020;5:41.

17. Moorthy AK. COVID-19 hit India's pharma sector but it can use a shortage of Chinese APIs to emerge as a dominant player, $\begin{array}{lll}\text { News18; } 2020 . & \text { Available }\end{array}$ https://www.news18.com/news/opinion/covid-19-hit-indiaspharma-sector-but-it-can-use-shortage-of-chinese-apis-toemerge-as-a-dominant-player-2633511.html. [Last accessed on 12 Aug 2020]

18. Raghavan P. Explained why the China factor has led to an increase in the price of heparin; will other drugs follow. The
Indian Express; 2020. Available from: https:// indianexpress.com/article/explained/explained-why-chinafactor-has-led-to-an-increase-in-price-of-heparin-will-otherdrugs-follow-6487000/. [Last accessed on 13 Aug 2020]

19. Bansal M, Walia MK. Covid 19-an overview on epidemiology, symptoms, prevention, management, treatment, and role of health workers. Int J Appl Pharm 2020;12:36-41.

20. Dey S. Supply constraints push up COVID-19 drug prices by $50 \%$, The Times of India; 2020. Available from: https://timesofindia.indiatimes.com/business/indiabusiness/supply-constraints-push-up-covid-19-drug-priceby $50 \% /$ articleshow/76740210.cms. [Last accessed on 13 Aug 2020]

21. Ayati N, Saiyarsarai P, Nikfar S. Short and long term impacts of COVID-19 on the pharmaceutical sector. DARU J Pharm Sci 2020;1-7 https://doi.org/10.1007/s40199-020-00358-5.

22. Sharma U. Strategic short term measures needed on the API front: Pharma experts, Express Pharma; 2020. Available from: https://www.expresspharma.in/latest-updates/strategicshort-term-measures-needed-on-the-api-front-pharmaexperts/. [Last accessed on 13 Aug 2020]

23. Santoki AA, Parekh MH. Marketing strategies during covid-19. JCR 2020;7:2309-15.

24. Jha R, Sharma A. India's pharmaceutical industry: global supply chain and governance in the post-COVID-19 world; 2020. p. 125. http://dx.doi.org/10.2139/ssrn.3622794

25. ET Bureau. Government launches schemes to boost production of local bulk drugs medical devices, The Economic Times; 2020. Available from: https://health.economictimes.indiatimes.com/ news/policy/govt-launches-schemes-to-boost-production-oflocal-bulk-drugs-medical-devices/77196277. [Last accessed on 13 Aug 2020]

26. Kumar A, Luthra S, Mangla SK, Kazancoglu Y. COVID-19 impact on sustainable production and operations management. Sust Oper Comp 2020;1:1-7.

27. Sharma GD, Talan G, Jain M. Policy response to the economic challenge from COVID-19 in India: a qualitative enquiry. J Public Affairs 2020;e2206:1-16.

28. Ahmed A, Chakraborty D, Bhattacharyya R. The recent coronavirus (COVID-19) pandemic: a review of issue for Indian pharmaceutical exports. Foreign Trade Rev 2020;55:418-35.

29. Sharma A, Gupta P, Jha R. COVID-19: impact on health supply chain and lessons to be learnt. J Health Management 2020;22:248-61.

30. Elavarasan RM, Pugazhendhi R. Restructured society and environment: a review on potential technological strategies to control the COVID-19 pandemic. Sci Total Environ 2020;725:118.

31. Meghana A, Aparna Y, Chandra SM, Sanjeev S. Emergency preparedness and response (EP and R) by pharmacy professionals in India: Lesson from the COVID-19 pandemic and the way forward. Res Social Adm Pharm 2020. p. S15517411 ,

3043-X. https://doi.org/10.1016/j.sapharm.2020.04.028.

32. Piatek OI, Ning JCM, Touchette DR. National drug shortages worsen during COVID-19 crisis: proposal for a comprehensive model to monitor and address critical drug shortages. Am J Health Syst Pharm 2020;77:1778-85.

33. Kuo S, Ou HT, Wang CJ. Managing medication supply chains: lessons learned from Taiwan during the COVID-19 pandemic and preparedness planning for the future. J Am Pharm Assoc 2020. p. 1-4. https://doi.org/10.1016/j.japh.2020.08.029.

34. Liu SCH, Huang MC, Horng SS. TFDA takes actions to help mitigate supply disruption or shortages of drug. J Formosan Med Assoc 2020;119:1459-60.

35. Mircheva RD. A crisis within the crisis: the impact of COVID-19 and brexit on supply chains in the pharmaceutical industry. Central Eastern European Online Library 2020;64:352-68.

36. Biswas D, Sultana P. Policing during the time of corona: The Indian context. Policing 2020;0:1-8. 